\title{
Czerniaki skóry — zasady postępowania diagnostyczno-terapeutycznego w 2016 roku
}

\author{
Piotr Rutkowski ${ }^{1}$, Piotr J. Wysocki ${ }^{2}$, Anna Nasierowska-Guttmejer ${ }^{3}$, Jacek Fijuth ${ }^{4}$, \\ Ewa Kalinka-Warzocha ${ }^{5}$, Tomasz Świtaj ${ }^{1}$, Arkadiusz Jeziorski ${ }^{4}$, Milena Szacht ${ }^{1}$, \\ Wojciech Zegarski ${ }^{6}$, Wojciech M. Wysocki ${ }^{7}$, Lidia Rudnicka ${ }^{8}$, \\ Witold Owczarek ${ }^{9}$, Maciej Krzakowski ${ }^{1}$
}

Podstawą klinicznej diagnostyki różnicowej czerniaków skóry i kwalifikacji do biopsji wycinającej jest obecnie dermoskopia. Dla ustalenia rozpoznania i określenia najważniejszych czynników rokowniczych podstawowe znaczenie ma biopsja wycinająca podejrzanych w kierunku wczesnego czerniaka zmian barwnikowych skóry (wycięcie całej grubości skóry i powierzchownej warstwy tkanki tłuszczowej). Wczesne rozpoznanie i chirurgiczne usunięcie czerniaka nie tylko poprawia rokowanie, ale daje szansę wyleczenia około $90 \%$ chorych. Kolejne etapy postępowania terapeutycznego obejmują kwalifikację chorych do radykalnego wycięcia blizny po biopsji wycinającej z właściwymi marginesami oraz wykonania biopsji węzła wartowniczego. W przypadku przerzutów do regionalnych węzłów chłonnych postępowaniem z wyboru jest wykonanie radykalnej limfadenektomii. Zaleca się włączanie chorych na czerniaki skóry o wysokim ryzyku nawrotu (przerzuty do węzłów chłonnych i/lub owrzodzenie pierwotnej zmiany) do prospektywnych badań klinicznych nad leczeniem uzupełniającym. Obecność przerzutów odległych wiąże się ze złym rokowaniem. W sytuacji uogólnienia nowotworu konieczne jest wykonanie badania w kierunku mutacji genu $B R A F$. Długoletnie przeżycia dotyczą głównie chorych poddanych resekcji pojedynczych ognisk przerzutowych. W systemowym leczeniu — przede wszystkim pierwszej linii — u chorych z obecnością mutacji BRAF V600 znajduje zastosowanie inhibitor BRAF — wemurafenib lub dabrafenib (preferencyjnie w skojarzeniu z inhibitorem MEK) oraz — niezależnie od statusu mutacji BRAF — immunoterapia przeciwciałami anty-PD-1 (niwolumab lub pembrolizumab), ewentualnie ipilimumab (przeciwciało anty-CTLA4).

\section{Recommendations for diagnosis and therapy of cutaneous melanoma}

Dermoscopy is currently the standard method for clinical differential diagnosis of cutaneous melanoma and for qualifying a lesion for excision biopsy. Full thickness excision biopsy of suspicious melanomatous skin lesions is likely to be diagnosed as early melanomaand is crucial in establishing diagnosis and defining prognostic factors. Early diagnosis and surgical removal of cutaneous melanoma not only improves prognosis, but it is also associated with approximately $90 \%$ likelihood of cure. Next steps in the therapeutic management of cutaneous melanoma following

\footnotetext{
${ }^{1}$ Centrum Onkologii — Instytut im. Marii Skłodowskiej-Curie w Warszawie

${ }^{2}$ Zachodniopomorskie Centrum Onkologii w Szczecinie

${ }^{3}$ Centralny Szpital Kliniczny MSW w Warszawie

${ }^{4}$ Uniwersytet Medyczny w Lodzi

${ }^{5}$ Regionalny Ośrodek Onkologiczny w Łodzi

${ }^{6}$ Centrum Onkologii w Bydgoszczy

Collegium Medicum w Bydgoszczy, Uniwersytet Mikołaja Kopernika

${ }^{7}$ Centrum Onkologii — Instytut im. Marii Skłodowskiej-Curie, Oddział w Krakowie

${ }^{8}$ Uniwersytet Medyczny w Warszawie

${ }^{9}$ Wojskowy Instytut Medyczny w Warszawie
} 
excision biopsy are radical scar excision with adequate margins and sentinel lymph node biopsy. Radical lymph node dissection is recommended in case of regional lymph node metastases. High-risk patients (lymph node involvement and/or ulcerated primary lesion) should be advised to participate in prospective clinical trials on adjuvant therapy. Melanoma patients with distant metastases are still characterised by poor outcomes. In patients with metastatic disease testing for the presence of BRAF gene mutation is mandatory Patients with metastatic disease should be considered for participation in clinical trials. Long-term survival is confined to selected group of patients undergoing resection of isolated metastatic lesions. In systemic (mainly first-line) therapy of patients with BRAF V600 mutation BRAF inhibitor, vemurafenib or dabrafenib (preferentially in combination with MEK inhibitor) may be employed and independently of mutational status immunotherapy with anti-PD-1 antibodies (nivolumab or pembrolizumab), and eventually ipilimumab (anti-CTLA4 antibody) may be used.

NOWOTWORY Journal of Oncology 2015; 65, 6: 501-516

Słowa kluczowe: czerniak skóry, rozpoznawanie, leczenie

Key words: cutaneous melanoma, diagnosis, therapy

\section{Wstęp}

Czerniaki skóry są złośliwymi nowotworami wywodzącymi się z neuroektodermalnych komórek melanocytarnych. W Polsce czerniaki występują względnie rzadko — standaryzowany współczynnik zachorowalności wynosi około 4,9/100000, co odpowiada w ostatnich latach około 3100 zachorowaniom rocznie (około 1400 u mężczyzn i około $1700 \mathrm{u}$ kobiet). Czerniaki są jednak nowotworami o największej dynamice wzrostu liczby zachorowań. W Polsce w latach 1980-2010 liczba zachorowań zwiększyła się niemal 3-krotnie. Mediana wieku zachorowania jest podobna dla obu płci i wynosi około 50 lat. Standaryzowane współczynniki umieralności osiągają wartości 2,3/100 000 u mężczyzn i 1,5/100 000 u kobiet, co w ostatnich latach przekłada się odpowiednio na 700 i 630 zgonów z powodu czerniaka [1, 2].

Za najistotniejsze czynniki zwiększonego ryzyka zachorowania uznaje się: intensywne działanie promieniowania ultrafioletowego naturalnego (promienie słoneczne) i sztucznego (np. łóżka opalające, solaria), stałe drażnienie mechaniczne lub chemiczne, niską zawartość barwnika w skórze oraz predyspozycje genetyczne (np. rodzinny zespół znamion atypowych — familial atypical mole syndrome - FAMS).

Możliwa ze względu na lokalizację wczesna identyfikacja ogniska pierwotnego (mikrostopniowanie I — biopsja wycinająca zmiany pierwotnej) i przerzutów do regionalnych węzłów chłonnych (mikrostopniowanie ll — biopsja węzłów wartowniczych) stwarza unikalną możliwość wyleczenia czerniaka skóry.

W chwili rozpoznania u około $90 \%$ chorych czerniak skóry ma charakter zmiany miejscowej, podczas gdy stadium regionalnego zaawansowania i uogólnienia występuje pierwotnie jedynie - u odpowiednio - około 10\% i < 5\% chorych. W ostatnich latach nastąpił postęp w leczeniu systemowym chorych na uogólnionego czerniaka skóry, niemniej wskaźniki przeżyć w tej grupie chorych są nadal niezadowalające. Wskaźniki 5-letnich przeżyć wynoszą we wczesnych postaciach czerniaka $60 \%-95 \%$ oraz $20 \%-70 \%$ i 5\%-10\% w stadium regionalnego zaawansowania i uogólnienia.

Celem pracy jest przedstawienie aktualnych zaleceń dotyczących diagnostyki i terapii tego nowotworu opracowanych na podstawie danych naukowych oraz doświadczeń ekspertów, które są powszechnie akceptowane i wymagają upowszechnienia'. Podstawową i obowiązującą zasadą powinno być postępowanie prowadzone w ramach wielodyscyplinarnych zespołów, których członkowie mają doświadczenie w diagnostyce i leczeniu czerniaków [3, 4].

\section{Objawy i diagnostyka Objawy kliniczne}

Podejrzenie czerniaka skóry mogą nasuwać zmiany skóry, które rozwinęły się de novo lub na podłożu znamienia barwnikowego (zgrubienie, zmiana powierzchni, zabarwienia i brzegów lub wystąpienie swędzenia i/lub krwawienia). Kliniczne objawy są niekiedy grupowane w systemach mających ułatwić rozpoznawanie (tab. I). Podstawowy jest system kliniczny $A B C D E$, używany obecnie głównie do celów dydaktycznych, gdyż pozwala na identyfikację znaczącej części czerniaków zaawansowanych. Nie może on jednak służyć jako (przesiewowe) narzędzie diagnostyczne w praktyce klinicznej. System kliniczny ABCDE nie pozwala na właściwe zakwalifikowanie ok. 50\% czerniaków, w tym w szczególności czerniaków wczesnych (poniżej $5 \mathrm{~mm}$ ), czerniaków guzkowych (które zazwyczaj nie wykazują heterogenności barw i nieregularności brzegu) oraz czerniaków bezbarwnikowych, a także zmian w obrębie skóry owłosionej głowy [1].

\footnotetext{
${ }^{1}$ Spotkanie ekspertów i współautorów tego doniesienia odbyło się 23 października 2015 roku w Warszawie. Przedstawione zasady reprezentuja stanowisko autorów odnośnie najbardziej uzasadnionego postępowania diagnostyczno-terapeutycznego, ale powinny być interpretowane w kontekście indywidualnej sytuacji klinicznej.
} 


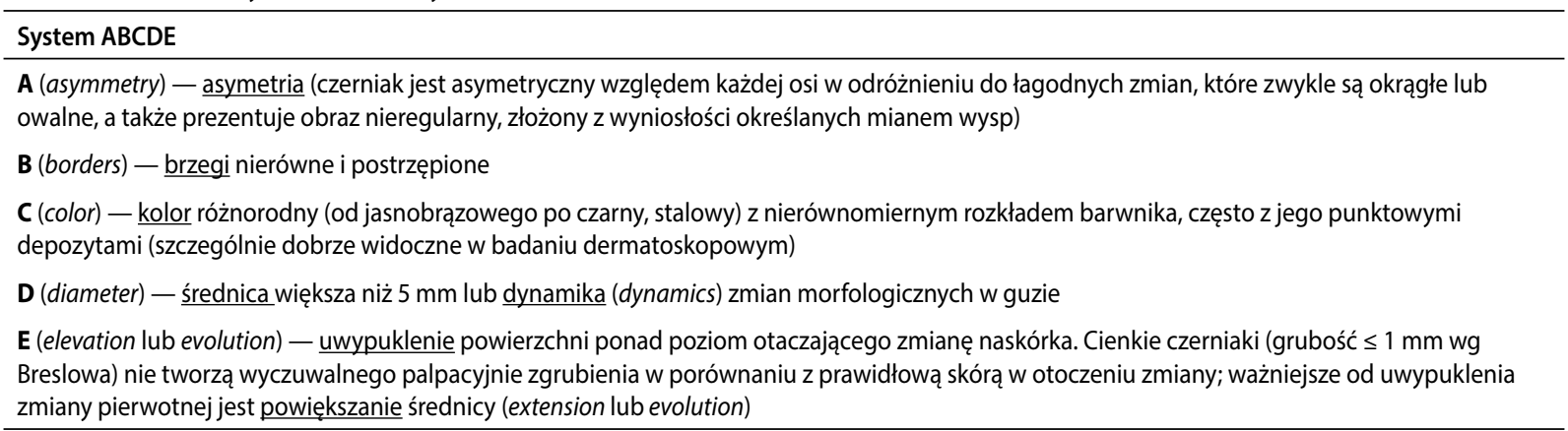

Cienkie czerniaki (< $1 \mathrm{~mm}$ grubości wg Breslowa) są przeważnie wykrywane przypadkowo w czasie badania lekarskiego, natomiast bardzo rzadko przez chorego lub członków rodziny.

\section{Diagnostyka}

Wywiad chorobowy powinien uwzględniać pytania o stan skóry (tzn. informację o zmianach w obrębie istniejących znamion na skórze lub wystąpieniu nowych znamion) oraz czynniki zwiększające ryzyko zachorowania na czerniaki skóry (np. oparzenia słoneczne, korzystanie z solarium, występowanie czerniaków w rodzinie).

Najważniejszym elementem pozwalającym na wczesne rozpoznanie jest badanie skóry, które powinno być wykonywane przez każdego lekarza podczas wizyty chorego w ambulatorium lub w trakcie hospitalizacji. Zasadą badania jest ocena skóry całego ciała w dobrym oświetleniu z uwzględnieniem okolic trudno dostępnych (głowa, stopy, przestrzenie międzypalcowe, okolice narządów płciowych i odbytu).

Zalecanym badaniem, wykorzystywanym we wstępnej diagnostyce, jest dermoskopia (dermatoskopia) lub wideodermoskopia. Dzięki dermoskopii możliwa jest poprawa czułości diagnostycznej o około 30\%. Najprostsza technika dermoskopowa, tzw.,trzypunktowa skala dermoskopowa”, opiera się na podejrzeniu klinicznym czerniaka w przypadku spełnienia dwu z trzech następujących kryteriów: 1) asymetryczny rozkład struktur w obrębie zmiany, 2) atypowa siatka barwnikowa, 3) niebiesko-biały welon. Czułość tej metody diagnostycznej dochodzi do 96,3\%, a jej swoistość do 94,2\%. Inne metody analizy dermoskopowej, w tym metoda dermoskopowa $A B C D$, analiza wzoru, skala siedmiopunktowa, metoda Menziesa, lub algorytm CASH (color, architecture, symmetry, homogeneity), charakteryzuje porównywalna czułość przy nieco większej swoistości. Należy podkreślić, że te systemy oceny dermoskopowej nie znajdują zastosowania w ocenie zmian w "lokalizacjach szczególnych", w tym zmian na skórze dłoni i stóp, na skórze owłosionej głowy, skórze twarzy lub błonach śluzowych jamy ustnej oraz narządów płciowych. W takich przypadkach niezbędne jest zastosowanie algorytmów dermoskopowych opracowanych odrębnie dla specyfiki skóry w każdej lokalizacji.
W przypadku zespołu znamion atypowych dobrą praktyką, dostępną dla wszystkich, jest gromadzenie dokumentacji fotograficznej zmian lub całej powierzchni skóry i porównywanie wykonanych zdjęć oraz obserwowanych zmian skórnych w kolejnych sekwencjach czasowych. Warto także rekomendować pacjentom samodzielny pomiar linijką obserwowanych zmian w regularnych (np. co 3 miesiące) odstępach czasu - sposób ten pozwala na prostą obiektywizację oceny ewentualnego powiększania się zmiany. W przypadkach wątpliwych, gdy biopsja wycinająca nie jest możliwa (na przykład przy podejrzeniu czerniaka w obrębie rozległych znamion wrodzonych u małych dzieci lub na twarzy) zalecanym badaniem jest refleksyjna laserowa skanningowa mikroskopia konfokalna skóry.

Podstawą rozpoznania czerniaków skóry jest histopatologiczne badanie całej wyciętej zmiany barwnikowej. Postępowanie inne niż biopsja wycinająca (tzw. mikrostopniowanie I) nie daje prawidłowego rozpoznania.

Po uzyskaniu rozpoznania histopatologicznego czerniaka skóry należy wdrożyć leczenie zgodnie z oceną stopnia zaawansowania (patrz poniżej).

Badania dodatkowe wykonywane w procesie diagnostycznym w celu oceny zaawansowania pierwotnego czerniaka obejmują: podstawowe badania krwi (morfologia, próby wątrobowe, aktywność dehydrogenazy mleczanowej - LDH), zdjęcie rentgenograficzne (RTG) klatki piersiowej (w projekcji tylno-przedniej i bocznej) oraz ocenę ultrasonograficzną (USG) jamy brzusznej i ewentualnie regionalnych węzłów chłonnych. $U$ chorych bezobjawowych nie są konieczne inne badania dodatkowe (w tym - badania tomografii komputerowej - TK i pozytonowej tomografii emisyjnej - PET-TK). Wykonanie badania TK lub PET-TK należy rozważyć u chorych z rozpoznaniem czerniaków skóry w stopniu III (zwłaszcza przy obecności klinicznych przerzutów do węzłów chłonnych) lub izolowanych przerzutów do narządów odległych. W przypadku klinicznych przerzutów do węzłów chłonnych pachwinowych wskazane jest wykonanie tomografii komputerowej lub rezonansu magnetycznego (MR) miednicy.

U chorych z przerzutami czerniaka do węzłów chłonnych lub skóry z nieznanego ogniska pierwotnego obowiązuje 
Tabela II. Kliniczna diagnostyka różnicowa czerniaka skóry

\begin{tabular}{|c|c|}
\hline Wczesny czerniak skóry & $\begin{array}{l}\text { - znamię barwnikowe/melanocytarne łagodne (naevus pigmentosus), znamię łączące (naevus } \\
\text { melanocyticus junctionalis, marginalis), znamię złożone (naevus melanocyticus compositus) } \\
\text { - znamiona atypowe } \\
\text { - znamię błękitne (naevus coeruleus) } \\
\text { - plama soczewicowata (lentigo simplex) } \\
\text { - rogowacenie słoneczne barwnikowe } \\
\text { - powierzchowny rak podstawnokomórkowy skóry (carcinoma basocellulare superficiale) } \\
\text { - znamię Spitza } \\
\text { - pozasutkowa postać choroby Pageta } \\
\text { - tatuaż }\end{array}$ \\
\hline Czerniak rozwinięty (zaawansowany miejscowo) & $\begin{array}{l}\text { - brodawka łojotokowa (verruca seborrhoica, keratosis seborrhoica) } \\
\text { - włókniak twardy skóry (dermatofibroma) } \\
\text { - rogowiak kolczystokomórkowy (keratoacanthoma) } \\
\text { - rak podstawnokomórkowy barwnikowy (carcinoma basocellulare pigmentosum) } \\
\text { - naczyniak (haemangioma) } \\
\text { - wynaczynienie żylne } \\
\text { - ziarniniak ropotwórczy, ziarniniak naczyniowy (granuloma pyogenicum, teleangiectaticum) } \\
\text { - barwnikowy torbielak potowy } \\
\text { - mięsak Kaposiego } \\
\text { - kłębczak } \\
\text { - inne guzy przydatkowe, szczególnie barwnikowe } \\
\text { - grzybica paznokci } \\
\text { - krwiak podpaznokciowy lub podrogowy }\end{array}$ \\
\hline
\end{tabular}

staranne poszukiwanie ewentualnej zmiany pierwotnej (zwłaszcza na skórze owłosionej głowy, błonach śluzowych) oraz zebranie starannego wywiadu (np. w kierunku zmian poddanych elektrokoagulacji).

\section{Różnicowanie}

Stany, które należy uwzględniać podczas różnicowania wczesnego i rozwiniętego czerniaka skóry, przedstawia tabela II.

\section{Rozpoznanie histopatologiczne - biopsja wycinająca zmiany skórnej (mikrostopniowanie I)}

Biopsja wycinająca zmiany skóry podejrzanej klinicznie o czerniaka jest postępowaniem z wyboru, gdyż pozwala na potwierdzenie rozpoznania mikroskopowego czerniaka oraz uzyskanie informacji o najważniejszych czynnikach rokowniczych, które służą planowaniu dalszego postępowania leczniczego (mikrostopniowanie) [1, 3-5]. Nie ma wskazań do „profilaktycznego" wycięcia znamion, które nie są podejrzane o czerniaka skóry.

Badanie patomorfologiczne materiału uzyskanego na drodze biopsji wycinającej składa się z badania makro- i mikroskopowego z określeniem cech obowiązkowo i warunkowo badanych i zawartych w raporcie histopatologicznym (http://www.pol-pat.pl/pliki/files/standardy_pdf/1.2_czerniak.pdf):

I. Badanie makroskopowe

a) wielkość wyciętego fragmentu skóry ze zmianą (3 wymiary)

b) wielkość zmiany (2 wymiary);

c) zabarwienie (jednolite, niejednolite),

d) brzeg zmiany (regularny, nieregularny); e) guzek (obecny, nieobecny);

f) margines (boczny, w głębi).

II. Badanie mikroskopowe Cechy mikroskopowe oceniane obowiązkowo:

a) grubość nacieku wg Breslowa w mm mierzona od warstwy ziarnistej naskórka lub dna owrzodzenia do najgłębiej naciekających gniazd melanocytów;

b) obecność lub brak owrzodzenia obejmującego całą grubość pokrywającego guz naskórka oraz określenie jego rozległości na podstawie średnicy lub odsetka zajętej powierzchni guza;

c) liczba figur podziału liczona w polu $1 \mathrm{~mm}^{2}$ o największej aktywności mitotycznej;

d) fazy wzrostu [horyzontalna (radialna) — śródnaskórkowa, in situ z mikroinwazją oraz strzałkowa (wertykalna), zawsze inwazyjna skórna];

e) marginesy chirurgiczne, najbliższy obwodowy (od składnika in situ i inwazyjnego) oraz w głębi;

f) stopień zaawansowania pT; Cechy warunkowo określane w raporcie histopatologicznym:

g) obecność stopnia regresji;

h) głębokość naciekania według Clarka (poziomy I, II, III, IV, V);

i) podtyp histologiczny [czerniak szerzący się powierzchownie (superficial spreading melanoma - SSM), czerniak powstający w plamie soczewicowatej lub plamie starczej Hutchinsona, zwany czerniakiem lentiginalnym (lentigo maligna melanoma - LMM), czerniak guzkowy (nodular melanoma - NM), czerniak odsiebnych części kończyn - podpaznokciowy (acral lentiginous melanoma - ALM), inne typy — np. desmoplastyczny]; 


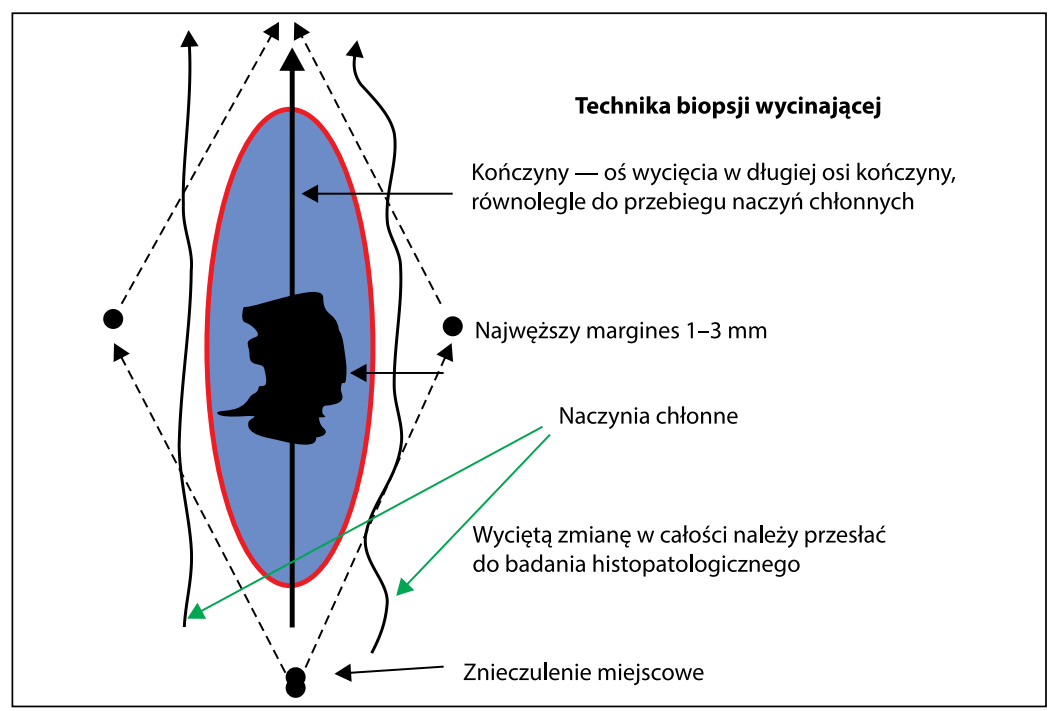

Rycina 1. Prawidłowy kierunek cięcia przy wykonywaniu biopsji wycinającej. Wrzecionowate wycięcie podejrzanej zmiany barwnikowej prowadzone jest równolegle do przebiegających w pobliżu naczyń chłonnych (w kierunku najbliższego spływu chłonnego) i w większości przypadków pozwala na pierwotne zszycie rany

j) obecność lub brak naciekania naczyń chłonnych i krwionośnych;

k) obecnośćlub brakmikroskopowych ognisk satelitarnych (ogniska z melanocytów średnicy powyżej 0,05 mm w odległości powyżej $0,3 \mathrm{~mm}$ i do $2 \mathrm{~cm}$ od składnika inwazyjnego guza pierwotnego czerniaka - cecha N);

I) typ komórki (epitelioidna, wrzecionowata, mała, pleomorficzna, inna);

ł) obecność i nasilenie nacieku limfocytarnego (TILs, oceniane tylko w komponencie wertykalnym; nieobecne, średnio obfite - TILs non-brisk, obfite - TILs brisk);

m) obecność lub brak naciekania pni nerwowych;

n) obecność znamienia.

Biopsja wycinająca jest prostym zabiegiem chirurgicznym i z reguły jest możliwa do wykonania w warunkach ambulatoryjnych. Wycięcie podejrzanej zmiany skórnej wykonuje się w miejscowym znieczuleniu nasiękowym, z marginesem bocznym 1-3 mm niezmienionej skóry. Preparat operacyjny oprócz całej grubości skóry zawiera również powierzchowną warstwę tkanki tłuszczowej, nie wycina się powięzi, a ranę zszywa się szwem pierwotnym. Cięcie skórne powinno być zgodne z długą osią ciała (ryc. 1), jedynie w obrębie twarzy należy stosować cięcie zgodnie z liniami estetycznymi. Nigdy nie powinno się wykonywać cięć poprzecznych (w lokalizacji kończynowej), które w przypadku reoperacji dają kosmetycznie bardzo zły efekt, a ze względów onkologicznych są błędem.

Wyniki aspiracyjnej biopsji cienko- lub gruboigłowej oraz biopsji nacinającej (wycinek) lub ścinającej (shave biopsy) nie dostarczają wiarygodnych informacji o zmianie pier- wotnej czerniaka zgodnie z wymogami systemu AJCC/UICC i metody te nie powinny być stosowane.

W przypadku, gdy zmiana jest bardzo duża i owrzodziała, można pobrać materiał do badania cytologicznego metodą odciskową (imprint cytology - przyciśnięcie szkiełka podstawowego do powierzchni guza i przesłanie tak pobranego materiału do badania cytologicznego).

Obecnie wiadomo, że określone podtypy czerniaków są związane ze specyficznymi mutacjami (jak mutacje KIT w czerniakach odsiebnych części kończyn/podpaznokciowych lub błon śluzowych). U chorych z uogólnionym (pierwotnie lub wtórnie) czerniakiem kwalifikujących się do leczenia systemowego obowiązkowe jest zbadanie obecności mutacji genu $B R A F$ na materiale utrwalonym [a także może być uzasadnione w sytuacji bardzo dużego ryzyka nawrotu choroby (stopień IIIC)], i opcjonalnie KIT oraz NRAS. Nie ma konieczności dodatkowego pobierania materiału w celu weryfikacji obecności zaburzeń molekularnych z ognisk przerzutowych. Badania genetyczne należy wykonywać w ośrodkach poddawanych kontroli jakości. Nie zaleca się wykonywania analizy mutacji u chorych na pierwotne czerniaki bez przerzutów [4].

\section{Biopsja węzłów wartowniczych (mikrostopniowanie II)}

Do biopsji węzła chłonnego wartowniczego kwalifikują się chorzy $[1,3,4]$ :

- po biopsji wycinającej z rozpoznaniem czerniaka skóry potwierdzonym badaniem histopatologicznym, ale nie po szerokim wycięciu ogniska pierwotnego;

- z grubością nacieku Breslowa $\geq 1,0 \mathrm{~mm}$; 
- z (mikro-)owrzodzeniem na powierzchni czerniaka niezależnie od grubości nacieku lub indeksem mitotycznym $\geq 1 / \mathrm{mm}^{2}$ ) [czerniak, którego ognisko pierwotne sklasyfikowano jako kategoria pT1b-T4b wg klasyfikacji TNM UICC/AJCC 2010]; według danych amerykańskiego Towarzystwa Chirurgii Onkologicznej (SSO - Society of Surgical Oncology), Amerykańskiego Towarzystwa Onkologii Klinicznej (ASCO - American Society of Surgical Oncology) oraz Europejskiego Towarzystwa Onkologii Medycznej (ESMO - European Society of Medical Oncology) można odstąpić od wykonywania biopsji węzła wartowniczego w czerniakach pT1b o grubości do $0,75 \mathrm{~mm}$ (niemniej należy nadal rozważyć ją przy stwierdzeniu owrzodzenia zmiany pierwotnej);

- bez klinicznych cech przerzutów w regionalnych węzłach chłonnych i narządach odległych.

Biopsja węzła wartowniczego jest obecnie niezbędną metodą oceny obecności mikroprzerzutów w węzłach chłonnych [6]. W 1999 roku Światowa Organizacja Zdrowia (WHO) stwierdziła, że biopsja węzła wartowniczego powinna być standardem postępowania u chorych na czerniaki skóry bez klinicznych cech przerzutów do regionalnych węzłów chłonnych [4, 6-8]. Podczas wykonywania biopsji węzła wartowniczego należy wykorzystywać limfoscyntygrafię przedoperacyjną oraz śródoperacyjną limfoscyntygrafię połączoną z wybarwieniem. Biopsję węzłów wartowniczych należy wykonywać po biopsji wycinającej czerniaka, jednoczasowo $z$ radykalnym wycięciem blizny po biopsji wycinającej czerniaka. Dostępne dane nie wskazują na negatywny wpływ na rokowanie po wykonywaniu biopsji węzła wartowniczego po upływie 6 tygodni od wycięcia ogniska pierwotnego. Dokładność metody zależy od współpracy lekarza medycyny nuklearnej, chirurga oraz patologa. Biopsja węzła wartowniczego jest diagnostyczną metodą „minimalnie inwazyjną" z uwagi na niewielką częstość powikłań pooperacyjnych wczesnych i późnych.

Badaniu patomorfologicznemu powinny być poddane wszystkie znalezione węzły chłonne. Z węzłów zawierających depozyty przerzutowe widoczne makroskopowo wystarczające jest pobranie jednego wycinka, podczas gdy w pozostałych przypadkach, jeśli jest to możliwe, należy wykonać seryjne skrawki węzła co 3-4 mm. Raport patologiczny opisujący ten materiał powinien zawierać liczbę znalezionych węzłów chłonnych, liczbę węzłów zawierających przerzuty, wielkość i lokalizację największego ogniska przerzutowego, obecność (lub brak) szerzenia się poza torebkę węzła oraz zajęcie naczyń. Badanie immunohistochemiczne z wykorzystaniem swoistych markerów (np. HMB45, Melan-A) uwidaczniać może obecność drobnych skupień komórek nowotworu.

Wyniki prospektywnego, wieloośrodkowego badania MSLT I (Multicenter Selective Lymphadenectomy Trial-1) wskazują, że biopsja węzła wartowniczego u chorych na czerniaki pozwala określić grupy wysokiego ryzyka rozsiewu nowotworu, pomaga we właściwym określeniu stopnia zaawansowania choroby, zapewnia znakomitą kontrolę regionalną i umożliwia kwalifikację chorych do badań klinicznych według jednakowych kryteriów [7]. W badaniu MSLT-1 nie wykazano poprawy czasu przeżycia do wystąpienia nawrotu choroby i czasu przeżycia całkowitego w całej analizowanej grupie chorych poddanych biopsji węzłów wartowniczych w porównaniu z grupą poddaną obserwacji. Jednakże w podgrupie chorych z obecnymi przerzutami do węzłów chłonnych przeżycia 10-letnie były znamiennie większe wśród chorych, którzy zostali poddani natychmiastowej limfadenektomii w przypadku stwierdzanego przerzutu do węzła wartowniczego w porównaniu z chorymi poddanymi takiemu leczeniu później, z powodu wykrycia klinicznie jawnych przerzutów $(62,1 \%$ vs 41,5\%; $p=0,006)$ [7].

Po stwierdzeniu w badaniu histopatologicznym przerzutów czerniaka w węzłach wartowniczych należy wykonać radykalną limfadenektomię, gdyż w pozostałych węzłach chłonnych (węzły chłonne niewartownicze - non-sentinel lymph node) przerzuty czerniaka stwierdza się za pomocą rutynowych metod histopatologicznych u około 20-30\% chorych [9].

Obecnie trwają badania kliniczne nad możliwością ograniczenia wykonywania uzupełniającej limfadenektomii u części chorych (submikroprzerzuty w węźle wartowniczym o średnicy $<0,1 \mathrm{~mm}$ lub w położeniu podtorebkowym o średnicy do $0,4 \mathrm{~mm}$ ) bez jednocześnie negatywnego wpływu na nawroty czerniaka [10].

\section{Ocena stopnia zaawansowania i czynniki rokownicze}

Identyfikacja klinicznych i patomorfologicznych cech rokowniczych ma na celu zrozumienie biologii nowotworu oraz ułatwienie zaplanowania właściwego leczenia dla indywidualnego chorego z uwzględnieniem ryzyka nawrotu choroby i prawdopodobieństwa przeżycia po leczeniu.

\section{Czynniki rokownicze}

Pierwotne ognisko czerniaka

Najważniejszymi czynnikami rokowniczymi u chorych na czerniaki skóry bez obecności przerzutów są grubość (według Breslowa) i obecność (mikro-)owrzodzenia ogniska pierwotnego. Obecnie stwierdzono również istotne znaczenie rokownicze określenia liczby mitoz w przypadku "cienkich" czerniaków o grubości $\leq 1 \mathrm{~mm}$ (pT1). Czynniki te znal zły zastosowanie w definiowaniu systemu TNM (tab. III) [4-6].

\section{Przerzuty w regionalnych węzłach chłonnych}

(III stopień zaawansowania klinicznego)

Obecność przerzutów w regionalnych węzłach chłonnych jest najistotniejszym czynnikiem determinującym rokowanie u chorych na czerniaki skóry. W przypadku obecności przerzutów najważniejszym czynnikiem jest liczba zmienionych przerzutowo regionalnych węzłów chłonnych. Istotnym 
Tabela III. Klasyfikacja oceny zaawansowania wg TNM AJCC/UICC z 2010 roku A. Kategorie systemu TNM

\begin{tabular}{|c|c|c|}
\hline Cecha T & Grubość nacieku [mm] & (Mikro-)owrzodzenie/mitozy \\
\hline \multicolumn{3}{|c|}{ pTis (in situ) } \\
\hline $\mathrm{T} 1$ & $\leq 1,0$ & $\begin{array}{l}\text { a: bez owrzodzenia }+ \text { indeks mitotyczny }<1 / \mathrm{mm}^{2} \\
\text { b: } z \text { owrzodzeniem lub indeks mitotyczny } \geq 1 / \mathrm{mm}^{2}\end{array}$ \\
\hline $\mathrm{T} 2$ & $1,01-2,00$ & $\begin{array}{l}\text { a: bez owrzodzenia } \\
\text { b: z owrzodzeniem }\end{array}$ \\
\hline T3 & $2,01-4,0$ & $\begin{array}{l}\text { a: bez owrzodzenia } \\
\text { b: z owrzodzeniem }\end{array}$ \\
\hline T4 & $>4,0$ & $\begin{array}{l}\text { a: bez owrzodzenia } \\
\text { b: z owrzodzeniem }\end{array}$ \\
\hline Cecha N & Liczba węzłów chłonnych z przerzutami & Typ przerzutu \\
\hline No & 0 & \\
\hline N1 & 1 & $\begin{array}{l}\text { a: mikroprzerzut* } \\
\text { b: makroprzerzut** }\end{array}$ \\
\hline N2 & $2-3$ & $\begin{array}{l}\text { a: mikroprzerzut* } \\
\text { b: makroprzerzut** } \\
\text { c: przerzuty in-transit/satelitoza bez przerzutów } \\
\text { w węzłach chłonnych }\end{array}$ \\
\hline N3 & $\begin{array}{l}4 \text { lub więcej węzły chłonne lub pakiet węzłowy } \\
\text { lub przerzuty in-transit/zmiany satelitarne } \\
\text { z jednoczesnymi przerzutami do węzłów } \\
\text { chłonnych }\end{array}$ & \\
\hline Cecha M & Umiejscowienie przerzutów & Poziom LDH w surowicy \\
\hline Mo & Bez przerzutów odległych & \\
\hline M1a & $\begin{array}{l}\text { Skóra, tkanka podskórna lub inne węzły chłonne } \\
\text { poza regionalnym spływem }\end{array}$ & Prawidłowy \\
\hline M1b & Płuca & Prawidłowy \\
\hline \multirow[t]{2}{*}{ M1c } & Inne niż ww. narządy trzewne & Prawidłowy \\
\hline & Każde umiejscowienie & Podwyższony \\
\hline
\end{tabular}

Definicje:

*Mikroprzerzut w węźle chłonnym — stwierdzony w badaniu mikroskopowym węzła chłonnego bezobjawowego (niepowiększonego) klinicznie po wykonanej biopsji węzła wartowniczego

**Makroprzerzut w węźle chłonnym — potwierdzony w badaniu mikroskopowym węzła chłonnego wyczuwalnego (powiększonego) klinicznie po terapeutycznej limfadenektomii

Satelitoza - naciek nowotworowy lub guzki (makro- lub mikroskopowo) w odległości do $2 \mathrm{~cm}$ od pierwotnego ogniska czerniaka skóry

In-transit - przerzuty w skórze lub tkance podskórnej w odległości ponad $2 \mathrm{~cm}$ od ogniska pierwotnego czerniaka skóry do poziomu najbliższego regionalnego spływu chłonki

$\mathrm{LDH}$ - dehydrogenaza mleczanowa

\section{B. Kategorie stopni zaawansowania}

\begin{tabular}{|c|c|c|c|c|c|c|}
\hline \multicolumn{4}{|c|}{ Stopnie kliniczne* } & \multicolumn{3}{|c|}{ Stopnie patologiczne ${ }^{* *}$} \\
\hline & $\mathrm{T}$ & $\mathrm{N}$ & $M$ & $\mathrm{~T}$ & $\mathbf{N}$ & $M$ \\
\hline 0 & Tis & No & MO & Tis & No & MO \\
\hline IA & T1a & No & MO & $\mathrm{T} 1 \mathrm{a}$ & No & Mo \\
\hline \multirow[t]{2}{*}{ IB } & $\mathrm{T} 1 \mathrm{~b}$ & No & MO & $\mathrm{T} 1 \mathrm{~b}$ & No & Mo \\
\hline & $\mathrm{T} 2 \mathrm{a}$ & No & MO & $\mathrm{T} 2 \mathrm{a}$ & No & Mo \\
\hline \multirow[t]{2}{*}{ IIA } & $\mathrm{T} 2 \mathrm{~b}$ & No & MO & $\mathrm{T} 2 \mathrm{~b}$ & No & MO \\
\hline & T3a & No & MO & T3a & No & MO \\
\hline \multirow[t]{2}{*}{ IIB } & $\mathrm{T} 3 \mathrm{~b}$ & No & MO & T3b & No & Mo \\
\hline & $\mathrm{T} 4 \mathrm{a}$ & No & MO & $\mathrm{T} 4 \mathrm{a}$ & No & MO \\
\hline IIC & $\mathrm{T} 4 \mathrm{~b}$ & No & MO & $\mathrm{T} 4 \mathrm{~b}$ & No & MO \\
\hline \multirow[t]{3}{*}{$\mathrm{III}^{\dagger}$} & Każdy T & N1 & Mo & & & \\
\hline & & $\mathrm{N} 2$ & & & & \\
\hline & & N3 & & & & \\
\hline
\end{tabular}


Tabela III (cd.). Klasyfikacja oceny zaawansowania wg TNM AJCC/UICC z 2010 roku

\begin{tabular}{|c|c|c|c|c|c|c|}
\hline \multicolumn{4}{|c|}{ Stopnie kliniczne* } & \multicolumn{3}{|c|}{ Stopnie patologiczne** } \\
\hline & $\mathrm{T}$ & $\mathrm{N}$ & $M$ & $\mathrm{~T}$ & $\mathrm{~N}$ & $M$ \\
\hline & & & IIIA & $\mathrm{T} 1-4 \mathrm{a}$ & $\mathrm{N} 1 \mathrm{a}$ & Mo \\
\hline & & & & $\mathrm{T1}-4 \mathrm{a}$ & $\mathrm{N} 2 \mathrm{a}$ & Mo \\
\hline & & & IIIB & $\mathrm{T} 1-4 \mathrm{~b}$ & N1a & Mo \\
\hline & & & & $\mathrm{T} 1-4 \mathrm{~b}$ & $\mathrm{~N} 2 \mathrm{a}$ & Mo \\
\hline & & & & T1-4a & N1b & Mo \\
\hline & & & & T1-4a & $\mathrm{N} 2 \mathrm{~b}$ & Mo \\
\hline & & & & $\mathrm{T} 1-4 \mathrm{a}$ & $\mathrm{N} 2 \mathrm{C}$ & Mo \\
\hline & & & IIIC & $\mathrm{T} 1-4 \mathrm{~b}$ & $\mathrm{~N} 1 \mathrm{~b}$ & Mo \\
\hline & & & & $\mathrm{T} 1-4 \mathrm{~b}$ & $\mathrm{~N} 2 \mathrm{~b}$ & Mo \\
\hline & & & & $\mathrm{T} 1-4 \mathrm{~b}$ & $\mathrm{~N} 2 \mathrm{c}$ & Mo \\
\hline & & & & Każdy T & N3 & Mo \\
\hline IV & Każdy T & Każdy N & Każdy M1 & Każdy T & Każdy N & Każdy M1 \\
\hline
\end{tabular}

*Stopniowanie kliniczne obejmuje mikrostopniowanie ogniska pierwotnego i kliniczną/radiologiczną ocenę obecności przerzutów, dlatego z zasady może być zastosowane tylko po całkowitym wycięciu ogniska pierwotnego czerniaka skóry (biopsji wycinającej) i ocenie obecności przerzutów w okolicznych węzłach chłonnych i narządach odległych

**Stopniowanie patologiczne zawiera mikrostopniowanie ogniska pierwotnego i ocenę patologiczną węzłów chłonnych regionalnego spływu: po biopsji węzła wartowniczego lub po radykalnej limfadenektomii (z wyjątkiem stopni 0 i IA, w których nie wykonuje się operacji w obrębie węzłów chłonnych regionalnego spływu) tW stopniowaniu klinicznym nie ma podgrup w stopniu III

czynnikiem jest rodzaj przerzutu — lepiej rokują chorzy z mikroprzerzutami (ogniska nowotworowe wykryte w trakcie badania mikroskopowego w niepowiększonym i klinicznie niewyczuwalnym węźle chłonnym - pobranym podczas biopsji węzłów wartowniczych) w porównaniu z makroprzerzutami (ogniska nowotworu rozpoznane w badaniu mikroskopowym w powiększonym i wyczuwalnym klinicznie węźle chłonnym). Dodatkowym istotnym czynnikiem wpływającym negatywnie na rokowanie chorych w grupie z przerzutami do węzłów chłonnych jest obecność naciekania poza torebkę węzła chłonnego przez komórki czerniaka.

\section{Przerzuty w narządach odległych (IV stopień zaawansowania klinicznego)}

Najważniejszymi czynnikami rokowniczymi u chorych z pozaregionalnymi przerzutami są lokalizacja przerzutów oraz aktywność LDH.

\section{Klasyfikacja stopni zaawansowania klinicznego}

Obecnie obowiązujący system klasyfikacji zaawansowania klinicznego i patologicznego czerniaka skóry według TNM pochodzi z rewizji przedstawionej w 2010 roku i został opracowany przez American Joint Committee on Cancer (AJCC) na podstawie analizy wieloczynnikowej danych ponad 38000 chorych (tab. III) [6].

\section{Zasady leczenia}

Leczenie chirurgiczne jest postępowaniem z wyboru u chorych na czerniaki. Po wykonaniu biopsji wycinającej podejrzanej zmiany barwnikowej i rozpoznaniu czerniaka skóry należy podjąć decyzję o ewentualnym „docięciu” bli- zny z odpowiednimi marginesami oraz wykonaniu biopsji wartowniczego węzła chłonnego. W przypadku stwierdzenia przerzutu w węźle wartowniczym lub potwierdzenia przerzutu w wyczuwalnych klinicznie regionalnych węzłach chłonnych za pomocą biopsji aspiracyjnej cienkoigłowej należy wykonać limfadenektomię spływu chłonnego. Obecnie leczenie uzupełniające po leczeniu chirurgicznym jest stosowane w wybranych przypadkach, zaś u chorych w stadium rozsiewu postępowanie powinno być indywidualizowane w zależności od sytuacji klinicznej. Podstawową i obowiązującą zasadą powinno być postępowanie prowadzone w ramach wielospecjalistycznych dyscyplinarnych zespołów, których członkowie mają doświadczenie w diagnostyce i leczeniu czerniaków.

\section{Leczenie chirurgiczne Ognisko pierwotne}

Radykalne leczenie ogniska pierwotnego czerniaka polega na doszczętnym wycięciu blizny po wykonanej biopsji wycinającej zmiany pierwotnej.

W oparciu o wyniki 6 wieloośrodkowych badań z losowym doborem chorych odstąpiono od wykonywania rozległych (tzn. margines $\geq 3 \mathrm{~cm}$ ) wycięć ogniska pierwotnego czerniaka na rzecz węższych marginesów zdrowych tkanek. Zalecane są następujące marginesy radykalnego leczenia zmiany pierwotnej czerniaka (wycięcie blizny po biopsji wycinającej zmiany pierwotnej): czerniak in situ - margines $5 \mathrm{~mm}$, czerniak o grubości $\leq 2 \mathrm{~mm}$ - margines $1 \mathrm{~cm}$, czerniak o grubości $>2 \mathrm{~mm}$ - margines $2 \mathrm{~cm}$ (tab. IV) [4, 5, 11]. Stosowanie marginesu większego niż $2 \mathrm{~cm}$ zmniejsza odsetek wznów miejscowych, ale nie poprawia przeżyć odległych. Bliznę po biopsji wycinającej czerniaka o gru- 
Tabela IV. Podsumowanie zaleceń NCCN (National Comprehensive Cancer Network) v. 3.2015, EORTC (European Organization for Research and Treatment of Cancer) oraz ESMO (European Society of Medical Oncology) odnośnie ostatecznego marginesu radykalnego wycięcia ogniska pierwotnego czerniaka skóry w zależności od jego grubości wg Breslowa

\begin{tabular}{ll}
\hline Grubość czerniaka (Breslow) & Zalecany margines kliniczny \\
\hline In situ & $0,5 \mathrm{~cm}$ \\
$\leq 2,0 \mathrm{~mm}$ & $1 \mathrm{~cm}$ \\
$>2,0 \mathrm{~mm}$ & $2 \mathrm{~cm}$ \\
\hline
\end{tabular}

bości $\leq 2 \mathrm{~mm}$ należy usunąć bez powięzi powierzchownej, zaś dla blizn po biopsji czerniaków z grubszym naciekiem dobrym marginesem od dołu jest wycięta powięź. Zasad tych nie stosujemy w przypadku lokalizacji czerniaka na twarzy, gdzie brak jest powięzi i marginesy wycięcia mogą być węższe. W przypadku lokalizacji podpaznokciowej czerniaków należy wykonać amputację dalszego paliczka palca.

\section{Regionalne węzły chłonne}

Chorzy na czerniaki skóry z przerzutami w regionalnych węzłach chłonnych stanowią grupę zróżnicowaną pod względem rokowania (przeżycia 5-letnie - 13\%-69\%). Prospektywne badania kliniczne nie potwierdziły korzyści płynących z wykonania elektywnej limfadenektomii u chorych bez klinicznych cech przerzutów czerniaka w węzłach chłonnych. Obecnie limfadenektomię u chorych na czerniaki skóry wykonuje się tylko w przypadku potwierdzenia obecności przerzutu w wartowniczych węzłach niepodejrzanych klinicznie spływów chłonnych (mikrostopniowane II) lub w przypadku stwierdzenia przerzutów na podstawie badania materiału pobranego drogą biopsji cienkoigłowej (w szczególnych przypadkach — biopsja chirurgiczna) z powiększonych i klinicznie podejrzanych węzłów chłonnych [1, 3, 7, 11].

\section{Limfadenektomia terapeutyczna}

Kwalifikując chorych do limfadenektomii, należy oprzeć się na badaniu klinicznym i wykluczyć przerzuty odległe (wykonać przynajmniej konwencjonalną RTG klatki piersiowej i USG jamy brzusznej). W przypadku podejrzenia przerzutów do narządów odległych należy kwalifikować chorych do dokładnych badań TK lub PET-TK (zwłaszcza ocena miednicy przy podejrzeniu przerzutów do węzłów chłonnych biodrowych lub zasłonowych) i MR. Badanie obrazowe w celu wykluczenia przerzutów do mózgu wykonuje się w przypadku wystąpienia objawów klinicznych.

Zakres terapeutycznej limfadenektomii w czerniakach skóry jest następujący:

a) w spływie pachowym należy usunąć wszystkie węzły chłonne zgodnie z definicją anatomiczną (3 grupy węzłów chłonnych wraz z powięziami je otaczającymi: piętro dolne - węzły przysutkowe i podłopatkowe, piętro środkowe - węzły środkowe pachy, piętro górne — węzły żyły pachowej i podobojczykowej); b) w spływie pachwinowym należy usunąć węzły chłonne okolicy pachwinowo-udowej, leżące poniżej więzadła pachwinowego w trójkącie udowym wraz z powięziami mięśni uda, węzły biodrowe leżące wzdłuż naczyń biodrowych oraz węzły chłonne dołu zasłonowego; (w przypadku niewielkich [o wielkości do $1 \mathrm{~mm}$ ] przerzutów do węzłów wartowniczych można ograniczyć limfadenektomię jedynie do węzłów pachwinowych);

c) w spływie szyjnym można wykonać operacje zmodyfikowane spełniające postulat maksymalnej doszczętności zabiegu, przy czym z reguły usuwa się struktury szyi zawierające węzły chłonne powierzchowne (przednie i tylne) oraz głębokie w jednym bloku, ograniczonym od tyłu powięzią głęboką szyi, od przodu mięśniem szerokim szyi.

Niekiedy istnieje konieczność wykonania limfadenektomii w obrębie dołu podkolanowego lub łokciowego.

\section{Wznowa miejscowa i przerzuty in-transit}

Terminy satelitoza (mikro- i makroskopowa), wznowa miejscowa oraz przerzuty in-transit stanowią pewną ciągłość i przedstawiają różne obrazy tego samego zjawiska patologicznego. Z reguły stan określany mianem wznowy miejscowej (często nawet po bardzo szerokim wycięciu ogniska pierwotnego) reprezentuje rozprzestrzenianie się czerniaków drogą otaczających naczyń chłonnych (mikrosatelity stają się makrosatelitami, a następnie mogą przechodzić w przerzuty in-transit). Z tego względu w większości opracowań wymienione postacie nawrotu czerniaka skóry analizowane są razem i wykazują podobne rokowanie (10-letnie przeżycie - 20\%-30\%). Podstawową metodą leczenia miejscowego wznowy miejscowej i przerzutów in-transit jest leczenie chirurgiczne. Leczenie powinno być indywidualizowane i zależy od liczby zmian, wielkości, lokalizacji i przebiegu klinicznego. W przypadku przerzutów in-transit postępowanie chirurgiczne obejmuje wycięcie policzalnych zmian $(<10)$ z marginesem mikroskopowym wolnym od nacieku czerniaka (makroskopowo może być wąski). Należy rozważyć zasadność wykonania kolejnego wycięcia miejscowego w przypadku pojawienia się następnej kaskady wysiewu in-transit po wcześniejszym i niedawnym (tzn. nie dłuższym niż okres jednego miesiąca) wycięciu zmian. W przypadku pojedynczych zmian nawrotowych można rozważyć ponowną biopsję węzła wartowniczego pod warunkiem, że od pierwotnej operacji i biopsji węzła wartowniczego upłynął dostatecznie długi czas (minimum 12 miesięcy, optymalnie > 24 miesięcy). Nie należy wykonywać amputacji w przypadku rozsiewu in-transit czerniaków skóry. W przypadkach mnogich/nieresekcyjnych należy rozważyć zastosowanie metod leczenia miejscowego: (ablacja laserem, radioterapia, krioterapia), immunoterapię doguzową (PV-10 lub interleukina-2) lub miejscową (imikwimod 
niezarejestrowany w tym wskazaniu) i elektrochemioterapię (ECT). W przypadku rozległych, mnogich zmian zlokalizowanych na kończynie preferowaną metodą jest izolowana chemioterapia perfuzyjna kończynowa w hipertermii (HILP - hyperthermic isolated limb perfusion), najczęściej z melfalanem, która może być stosowana wyłącznie w ośrodkach o odpowiednim przygotowaniu i doświadczeniu; niemożność zastosowania HILP jest wskazaniem do systemowego leczenia $[1,4,5,11,12]$.

\section{Leczenie uzupełniające}

Obecnie w praktyce klinicznej u chorych po radykalnej operacji zmiany pierwotnej i limfadenektomii nie ma wskazań do rutynowego stosowania systemowego leczenia uzupełniającego (chemioterapia lub immunoterapia), a radioterapia uzupełniająca może być rozważana tylko w ściśle określonych sytuacjach.

Jedynie interferon $\alpha-2 \mathrm{~b}$ w wysokich dawkach - na podstawie pozytywnego wyniku jednego z trzech badań Eastern Cooperative Oncology Group (ECOG) - ECOG 1684 - został zarejestrowany w USA i Unii Europejskiej dla czerniaków w stopniu zaawansowania IIB-III, a interferon $\alpha$-2b w niskich dawkach został zarejestrowany dla chorych w II stopniu w Europie [13, 14]. Podstawą rejestracji było znamienne wydłużenie czasu przeżycia całkowitego w okresie około 7-letniej obserwacji, które nie zostało potwierdzone po dłuższym czasie (12 lat). Wyniki badań pokazują w sposób powtarzalny (w 10 z 17 ocenionych badań) poprawę przeżyć wolnych od nawrotu choroby, przy czym ostatnie metaanalizy wykazują zmniejszenie względnego ryzyka nawrotu choroby o 17\%-18\% ( $p<0,0001)$ przy zastosowaniu leczenia adiuwantowego IFN. Dowody dotyczące poprawy przeżyć całkowitych są znacznie słabsze, pochodzą głównie z metaanaliz i przekładają się w całej grupie chorych na poprawę 5-letniego przeżycia całkowitego o około 3\%-5\%. Z uwagi na kontrowersyjne znaczenie uzupełniającego leczenia interferonem $\alpha$-2b chorych na czerniaki z grupy pośredniego i wysokiego ryzyka nawrotu oraz uwzględniając jego toksyczność, zastosowanie tej metody powinno być indywidualizowane. Wyniki metaanaliz wskazują, że podstawową grupą chorych odnoszącą korzyść z leczenia uzupełniającego IFN są chorzy z owrzodziałym ogniskiem pierwotnym czerniaka, zwłaszcza w podgrupie chorych z mikroprzerzutami (w węźle wartowniczym), a nie $z$ makroprzerzutami stwierdzanymi w klinicznie powiększonych węzłach chłonnych) [15]. W USA lekiem zarejestrowanym do leczenia uzupełniającego w grupie chorych po limfadenektomii z powodu przerzutów do regionalnych węzłów chłonnych jest ipilimumab, dla którego wykazano w badaniu $z$ losowym doborem chorych istotną poprawę przeżyć wolnych od nawrotu choroby przy jednocześnie dużej toksyczności tej terapii.
Inne metody immunoterapii (np. interleukina-2), szczepionki lub leki o działaniu cytotoksycznym nie majążadnego zastosowania w uzupełniającym leczeniu pooperacyjnym.

W indywidualnych przypadkach po leczeniu chirurgicznym czerniaków o dużym ryzyku możliwe jest zastosowanie uzupełniającej radioterapii - schemat dawkowania obejmuje hipofrakcjonowanie po 3-8 Gy/frakcję lub frakcjonowanie konwencjonalne w zależności od lokalizacji. Wskazaniem do uzupełniającej radioterapii po wycięciu guza pierwotnego mogą być następujące czynniki: czerniak desmoplastyczny wycięty z wąskimi marginesami, dodatnie marginesy chirurgiczne (zwłaszcza po wycięciu wznowy miejscowej), obecność ognisk satelitarnych, nasilony neurotropizm czy lokalizacja w regionie głowy i szyi (radioterapia jako samodzielna metoda może być zastosowana w przypadku rozległej zmiany typu LMM), stan po wycięciu wznowy miejscowej, zaś po limfadenektomii z powodu przerzutów do regionalnych węzłów chłonnych wskazaniami do uzupełniającej radioterapii mogą być: naciek pozatorebkowy węzła, zajęcie $\geq 4$ węzłów chłonnych (stopień IIIC), średnica przerzutu $>3 \mathrm{~cm}$, przerzuty w węzłach chłonnych szyi (od 2 zmienionych przerzutowo węzłów chłonnych lub przy wielkości przerzutu minimum $2 \mathrm{~cm}$ ), nawrót po resekcji $[16,17]$. Wyniki z jedynego zakończonego badania z losowym doborem chorych, które oceniało wartość uzupełniającej radioterapii (48 Gy w 20 frakcjach) po limfadenektomii w przypadku dużego ryzyka nawrotu, potwierdziły poprawę kontroli miejscowej po zastosowaniu napromieniania, bez wpływu na przeżycia całkowite i przy jednoczesnym zwiększeniu odległych powikłań lokoregionalnych.

\section{Leczenie chorych w stopniu uogólnienia}

Wyniki leczenia chorych na czerniaki skóry w IV stopniu zaawansowania są niezadowalające - mediana przeżycia wynosi około 6-12 miesięcy (jest dłuższa przy zastosowaniu nowych terapii), a 5-letnie przeżycia dotyczą około $10 \%$ chorych.

Czynnikami o znamiennym znaczeniu rokowniczym u chorych na czerniaka w stopniu IV są stan sprawności, poziom aktywności LDH oraz lokalizacja ognisk przerzutowych. W przypadku kwalifikacji chorego do leczenia chirurgicznego lub leczenia systemowego w IV stopniu zaawansowania należy dokonać oceny zaawansowania choroby za pomocą badań obrazowych lub badania PET-KT (jedynie izolowane ogniska przerzutowe kwalifikowane są do resekcji) [1].

W przypadku zmian wtórnych w skórze, tkankach miękkich, węzłach chłonnych (lepsze rokowanie) należy zawsze rozważać możliwość wycięcia. Podobnie należy postąpić w przypadku izolowanych przerzutów do narządów miąższowych. W przypadku zmian niemożliwych do wycięcia wybór postępowania zależy od obecności przerzutów w ośrodkowym układzie nerwowym, których stwierdzenie nakazuje w pierwszej kolejności rozważyć (decyzja zależna 
od umiejscowienia i liczby zmian) zastosowanie leczenia chirurgicznego lub napromieniania ośrodkowego układu nerwowego w celu opóźnienia wystąpienia krwawienia lub zaburzeń neurologicznych. W postępowaniu paliatywnym radioterapia znajduje również zastosowanie u chorych z przerzutami w tkankach miękkich (owrzodzenia i ból) i kościach (ból).

Postęp w uogólnionym czerniaku, przy niewielkiej skuteczności klasycznych leków cytotoksycznych, jest związany z immunoterapią nieswoistą za pomocą przeciwciał monoklonalnych anty-CTLA4 lub anty-PD-1, hamujących ogólnoustrojowe mechanizmy immunosupresji w celu indukcji odpowiedzi przeciwnowotworowej (aktywacja limfocytów T) oraz leczeniem ukierunkowanym molekularnie za pomocą inhibitorów kinaz serynowo-treoninowych. Nadal należy rozważać włączenie chorego na uogólnionego czerniaka do prospektywnych badań klinicznych.

Dakarbazyna jest jedynym zarejestrowanym w uogólnionym czerniaku lekiem cytotoksycznym, przy czym skuteczność leku jest ograniczona (obiektywna odpowiedź - 15\% chorych, mediana czasu trwania odpowiedzi -4 miesiące) [1, 3]. Jedynym schematem stosowania dakarbazyny opartym na wskazaniach rejestracyjnych jest podawanie leku przez 5 kolejnych dni w dobowej dawce $200 \mathrm{mg} / \mathrm{m}^{2}$. Możliwość 1-dniowego stosowania leku w wyższej dawce (850-1000 mg/m² co 3 tygodnie) nie została formalnie zatwierdzona, aczkolwiek jest postępowaniem bardziej użytecznym w praktyce. Paklitaksel w monoterapii lub stosowany łącznie z karboplatyną nie pozwala na długotrwałą kontrolę choroby w ramach drugiej linii leczenia. Badania z losowym doborem chorych nie potwierdziły większej skuteczności wielolekowych schematów z udziałem dakarbazyny w skojarzeniu z cisplatyną, alkaloidami barwinka (np. winblastyna) i pochodnymi nitrozomocznika (np. karmustyna) oraz tamoksyfenem. Stosowanie biochemioterapii (chemioterapia łącznie $z$ interleukiną-2 i interferonem $\alpha$-2b) nie poprawia przeżyć chorych w stosunku do chemioterapii. Wyniki nielicznych badań klinicznych wykazują, że interleukina-2 w monoterapii lub stosowana łącznie z interferonem $\alpha$-2b nieznacznie zwiększa wskaźnik odpowiedzi bez wpływu na czas przeżycia całkowitego, przy czym niepożądane działania leczenia są wyraźnie bardziej nasilone. Obecnie stosowanie chemioterapii powinno być ograniczone do sytuacji ratunkowych po niepowodzeniu leczenia ukierunkowanego molekularnie lub immunoterapii.

\section{Immunoterapia}

Ipilimumab został zarejestrowany do leczenia chorych na uogólnione czerniaki i wykazał — w porównaniu do peptydowej szczepionki gp100 w II linii —znamienne zwiększenie mediany przeżycia całkowitego (różnica — około 3,5 miesiąca) bez istotnego wpływu na czas przeżycia wolnego od progresji choroby $[18,19]$. Kinetyka i czas trwania odpowiedzi dla ipilimumabu jest odmienny niż w klasycznej chemioterapii — korzyść z leczenia obserwowana jest dopiero po 3-4 miesiącach, co ogranicza jego zastosowanie do chorych na zaawansowanego czerniaka o minimalnych objawach, dobrym stanie sprawności i powolnym przebiegu choroby oraz (z uwagi na profil bezpieczeństwa) bez towarzyszących chorób autoimmunologicznych. W związku z późnym występowaniem obiektywnych odpowiedzi wiążąca ocena skuteczności terapii ipilimumabem powinna być dokonana po 12 tygodniach od rozpoczęcia leczenia, zwłaszcza biorąc pod uwagę możliwość wystąpienia we wczesnym okresie terapii zjawiska paradoksalnej progresji związanej z naciekaniem guzów przez komórki czynne immunologicznie. W celu obiektywnej obrazowej oceny odpowiedzi na leczenie ipilimumabem wskazane jest stosowanie kryteriów odpowiedzi immunologicznej [18-20]. Obecnie nie znamy czynników predykcyjnych odpowiedzi na leczenie ipilimumabem. Zalecany schemat dawkowania ipilimumabu to dawka $3 \mathrm{mg} / \mathrm{kg} \mathrm{mc}$. podawana dożylnie co 3 tygodnie, ogółem podaje się 4 dawki.

Odsetek obiektywnych odpowiedzi na leczenie ipilimumabem jest niewielki (około 10\% chorych), długotrwałe korzyści odnosi ograniczona liczba chorych (20\%-25\%), jednak charakteryzują się oni wieloletnimi przeżyciami (najdłuższe obserwacje sięgają 10 lat). Problemem przy terapii ipilimumabem są działania niepożądane związane z reakcjami autoimmunologicznymi (działania niepożądane w stopniach 3-4 występują u około 20\%-25\% chorych). Do najczęstszych immunologicznych działań niepożądanych należą zmiany skórne, biegunki, hepatotoksyczność i endokrynopatie (w tym niedoczynność przysadki i tarczycy). Wystąpienie powyższych objawów u chorego leczonego ipilimumabem powinno skutkować jak najszybszym przesłaniem chorego do ośrodka o odpowiednim doświadczeniu w zakresie leczenia powikłań immunoterapii. W przypadku znacznego nasilenia objawów uniemożliwiających transport należy bezzwłocznie zastosować kortykosteroidy (deksametazon (lub równoważnik) 1-2 mg/kg m.c. na dobę) i prowadzić dalsze leczenie we współpracy z ośrodkiem referencyjnym. Odpowiednie algorytmy postępowania są dostępne [19] i powinny być rygorystycznie stosowane od momentu wystąpienia pierwszych objawów sugerujących toksyczność immunologiczną.

Leczenie ipilimumabem powinno być prowadzone jedynie w ośrodkach o najwyższym poziomie referencyjności, które zapewniają możliwość kompleksowego postępowania diagnostyczno-terapeutycznego. Nie jest uzasadnione podejmowanie wspomnianego leczenia w ośrodkach, które nie posiadają pełnych możliwości postępowania.

Obecnie immunoterapia w czerniakach skóry jest związana z zastosowaniem blokady punktów kontrolnych układu immunologicznego PD-1/PD-L1 w monoterapii (niwolu$\mathrm{mab} 3 \mathrm{mg} / \mathrm{kg}$ masy ciała co 2 tygodnie lub pembrolizumab 
w dawce $2 \mathrm{mg} / \mathrm{kg}$ masy ciała co 3 tygodnie) [21-23] lub w skojarzeniu z przeciwciałami anty-CTLA-4 (kombinacja niezarejestrowana w Unii Europejskiej) [24]. Preparaty te wykazały w warunkach klinicznych w monoterapii lub w kombinacji z ipilimumabem długotrwałą korzyść kliniczną u części chorych na zaawansowane czerniaki i znaczne odsetki odpowiedzi (sięgające 50\%), przy przeżyciach rocznych na poziomie $70 \%-80 \%$. Stosowanie pembrolizumabu jest związane z odsetkiem przeżyć 2-letnich około 50\%-60\%, przy akceptowalnej toksyczności (< 15\% w stopniu 3/4, czyli istotnie mniej niż dla ipilimumabu), choć najcięższe objawy również dotyczą immunologicznych działań niepożądanych.W badaniach potwierdzono jego większą skuteczność w odniesieniu do OS i PFS w porównaniu z ipilimumabem w pierwszej linii leczenia oraz w porównaniu z chemioterapią po niepowodzeniu wcześniejszego leczenia [23]. Podobne wyniki uzyskuje się dla leczenia niwolumabem $[21,22]$. W ostatnio opublikowanym badaniu klinicznym, gdzie porównano skuteczność niwolumabu w monoterapii, ipilimumabu w monoterapii oraz połączenia obu leków, niwolumab okazał się być bardziej skuteczny niż ipilimumab (mediana przeżycia wolnego od progresji choroby wynosiła odpowiednio 6,9 w porównaniu z 2,9 miesiąca), jednak najskuteczniejszą okazała się kombinacja leków; mediana przeżycia wolnego od progresji choroby to 11,5 miesiąca. Kombinacja leków była najlepszą opcją w przypadku obecności ekspresji PD-L1 w tkance nowotworowej poniżej 5\%. W przypadku ekspresji PD-L1 powyżej 5\% wyniki leczenia niwolumabem w monoterapii lub w skojarzeniu z ipilimumabem były porównywalne, nie przedstawiono jednak jak dotąd wyników dotyczących czasu przeżycia całkowitego [24]. Pod względem toksyczności istotne klinicznie działania niepożądane najczęściej miały miejsce w grupie chorych poddanej leczeniu skojarzonemu (stopień 3-4) dotyczył $55 \%$ chorych, w grupie przyjmującej niwolumab - 16\% i $27 \%$ ipilimumab w monoterapii.

W świetle wyników tych badań ipilimumab nie powinien już stanowić podstawowego rodzaju immunoterapii u chorych na zaawansowane czerniaki (gdyż przynosi gorsze wyniki niż przeciwciała anty-PD-1), zaś leczenie należy rozpoczynać od przeciwciał anty-PD-1 (pembrolizumab lub niwolumab) w monoterapii. Problem terapii skojarzonej z anty-CTLA-4 wymaga dalszych badań.

\section{Leczenie ukierunkowane molekularnie}

Mutacje w szlaku RAS/RAF/MEK/ERK kinazy MAP (MAPK) stwierdzane są w około 75\% przypadków czerniaka skóry. Dominującym mechanizmem prowadzącym do nadaktywności szlaku RAS/RAF/MAPK w czerniaku skóry jest mutacja genu kodującego kinazę BRAF, przy czym mutacje somatyczne w genie BRAF obserwuje się w 50\%-70\% czerniaków skóry powstających w miejscach nienarażonych na długotrwałe działanie promieni słonecznych. Opublikowane w 2011 roku wyniki rejestracyjnego badania III fazy z wemurafenibem w I linii u chorych z mutacją BRAFV600 wykazały odpowiedzi na leczenie u 48\% leczonych inhibitorem BRAF w porównaniu z 5\% otrzymujących dakarbazynę, jak również znaczącą poprawę przeżyć wolnych od progresji (różnica — około 5 miesięcy) i przeżyć całkowitych (różnica — około 3 miesiące) [25]. Wemurafenib został zarejestrowany do leczenia chorych na zaawansowane czerniaki z mutacją BRAF (oznaczanie tej mutacji jest możliwe w polskich ośrodkach za pomocą zwalidowanego testu). Pomimo że u większości chorych dochodzi do pojawiania się oporności na leczenie (mediana przeżyć wolnych od progresji wynosi 6-7 miesięcy), wyniki badania II-III fazy wykazały medianę przeżyć całkowitych u chorych na przerzutowe czerniaki na poziomie 13-16 miesięcy, co znaczenie przewyższa obserwowane wcześniej przeżycia w tej grupie chorych. Wemurafenib charakteryzuje się istotną toksycznością skórną (nadwrażliwość na promieniowanie UV), hepatotoksycznością typową dla inhibitorów kinaz, jak również prowadzi do powstawania wtórnych nowotworów (rak lub rogowiak kolczystokomórkowy skóry u niemal 20\% leczonych). Wtórne nowotwory skóry mogą się rozwinąć już w kilka tygodni po rozpoczęciu terapii wemurafenibem. Ich rozpoznanie jest wskazaniem do leczenia miejscowego, ale nie wymaga odstawienia leku. Niepożądane działania powodują dość często konieczność obniżenia dawki wemurafenibu. W 2012 roku potwierdzono skuteczność terapeutyczną innego inhibitora BRAF — dabrafenibu (charakteryzującego się skutecznością porównywalną do wemurafenibu, ale innym profilem toksyczności - m.in. mniejszą toksycznością skórną). Mediana PFS wyniosła 6,7 miesiąca dla dabrafenibu vs 2,9 miesiąca dla dakarbazyny, zaś raportowana w 2013 roku mediana przeżyć całkowitych przy leczeniu dabrafenibem wyniosła 18,2 miesiąca [26]. Oba leki są dostępne obecnie w Polsce w ramach programu lekowego w pierwszej linii leczenia chorych na zaawansowane czerniaki z potwierdzoną obecnością mutacji BRAF. W badaniu III fazy potwierdzono również skuteczność inhibitora MEK — trametynibu — w leczeniu chorych na przerzutowe czerniaki z obecnością mutacji BRAF [27]. Skuteczność inhibitorów MEK obserwowano również u chorych z mutacjami NRAS [28]. Najnowsze wyniki badań (COMBI-d, COMBI-v i coBRIM) wykazały, że u chorych na przerzutowe czerniaki z obecnością mutacji $B R A F$ zastosowanie kombinacji inhibitora BRAF i MEK (dabrafenib $z$ trametynibem lub wemurafenib $z$ kobimetynibem) przynosi lepsze efekty niż monoterapia bez zwiększenia toksyczności [29-31]. Mediana przeżyć przy tych lekach wydłużyła się do ok. 20-25 miesięcy, przy medianie PFS około 12 miesięcy.

Wymienione leki mają korzystne działanie również u chorych ze stabilnymi lub/i bezobjawowymi przerzutami w mózgu, co jak dotąd stanowiło miejsce niedostępne 
Tabela V. Rekomendowane badania kontrolne w czerniaku skóry

\begin{tabular}{|c|c|c|}
\hline & Rodzaj badania & Częstość wykonywanych badań \\
\hline $\begin{array}{l}\text { Wczesne czerniaki po wycięciu } \\
\text { ogniska pierwotnego bez } \\
\text { przerzutów do węzłów } \\
\text { chłonnych: stopnie IA(-IB) }\end{array}$ & $\begin{array}{l}\text { Badanie przedmiotowe i podmiotowe, zwłaszcza całej skóry } \\
\text { i regionalnych węzłów chłonnych oraz okolicy blizny po wyciętym } \\
\text { czerniaku } \\
\text { Zdjęcie rentgenowskie (RTG) klatki piersiowej — opcjonalnie } \\
\text { Inne badania [np. ultrasonografia (USG), TK] w przypadku stwierdzanych } \\
\text { podejrzanych objawów } \\
\text { USG regionalnych węzłów chłonnych, gdy nie wykonano biopsji węzła } \\
\text { wartowniczego w czerniakach skóry } \geq \text { pT1b } \\
\text { Nie ma wskazań do wykonywania żadnych badań dodatkowych oprócz } \\
\text { badania przedmiotowego u chorych po wycięciu czerniaka pT1a } \\
\text { Potrzeba edukacji chorego w kierunku samokontroli }\end{array}$ & $\begin{array}{l}\text { Co 6-12 miesięcy przez pierwsze } \\
5 \text { lat, następnie raz w roku } \\
\text { (kontrola może być prowadzona } \\
\text { poza ośrodkiem specjalistycznym) }\end{array}$ \\
\hline $\begin{array}{l}\text { Zaawansowane miejscowo } \\
\text { czerniaki po wycięciu ogniska } \\
\text { pierwotnego bez przerzutów } \\
\text { do węzłów chłonnych (stopnie } \\
\text { IIA-IIC) }\end{array}$ & $\begin{array}{l}\text { Badanie przedmiotowe i podmiotowe, zwłaszcza całej skóry } \\
\text { i regionalnych węzłów chłonnych oraz okolicy blizny po wyciętym } \\
\text { czerniaku } \\
\text { RTG klatki piersiowej, USG jamy brzusznej } \\
\text { Badanie morfologii i biochemii krwi (próby wątrobowe i stężenie } \\
\text { dehydrogenazy mleczanowej) — opcjonalnie } \\
\text { Inne badania [np. TK] w przypadku stwierdzanych podejrzanych } \\
\text { objawów } \\
\text { USG regionalnych węzłów chłonnych, gdy nie wykonano biopsji węzła } \\
\text { wartowniczego w czerniakach skóry } \geq \text { pT1b } \\
\text { W grupie chorych IIB-IIC można zastosować badania TK co } \\
\text { 6-12 miesięcy i opcjonalnie raz w roku badanie MR mózgu (przez } \\
\text { pierwsze 2-3 lata) } \\
\text { Potrzeba edukacji chorego w kierunku samokontroli } \\
\text { W stopniu IIC można stosować intensywniejsze badania kontrolne, jak } \\
\text { W stopiu III }\end{array}$ & $\begin{array}{l}\text { Co 3-6 miesięcy przez } \\
\text { pierwsze 2-3 lata, następnie co } \\
6-12 \text { miesięcy do } 5 \text { lat i raz w roku } \\
\text { po upływie } 5 \text { lat }\end{array}$ \\
\hline $\begin{array}{l}\text { Po wycięciu przerzutów do } \\
\text { okolicznych węzłów chłonnych } \\
\text { lub wznowy miejscowej/ogniska } \\
\text { satelitarnego/in-transit (stopnie } \\
\text { IIIA-IIIC) }\end{array}$ & $\begin{array}{l}\text { Badanie przedmiotowe i podmiotowe, zwłaszcza całej skóry } \\
\text { i regionalnych węzłów chłonnych oraz okolicy blizny po wyciętym } \\
\text { czerniaku } \\
\text { RTG klatki piersiowej } \\
\text { Badanie morfologii i biochemii krwi (próby wątrobowe i stężenie } \\
\text { dehydrogenazy mleczanowej) } \\
\text { USG jamy brzusznej i ewentualnie okolicy po usuniętych regionalnych } \\
\text { węzłach chłonnych } \\
\text { Ze względu na wysokie ryzyko nawrotu należy zastosować badania TK } \\
\text { co 6-12 miesięcy i opcjonalnie w stopniu IIIC raz w roku badanie MR } \\
\text { mózgu (przez pierwsze 2-3 lata) } \\
\text { Potrzeba edukacji chorego w kierunku samokontroli }\end{array}$ & $\begin{array}{l}\text { Co } 3 \text { miesiące przez pierwsze } \\
2 \text { lata, co 3-6 miesięcy przez } \\
\text { kolejne } 3 \text { lata i następnie raz } \\
\text { w roku po upływie } 5 \text { lat }\end{array}$ \\
\hline $\begin{array}{l}\text { Po leczeniu przerzutów odległych } \\
\text { (stopień IV) }\end{array}$ & $\begin{array}{l}\text { Ocena w badaniach obrazowych w zależności od lokalizacji mierzalnych } \\
\text { ognisk przerzutowych } \\
\text { Stężenie dehydrogenazy mleczanowej w surowicy }\end{array}$ & $\begin{array}{l}\text { Program wizyt kontrolnych } \\
\text { indywidualny dla danego chorego }\end{array}$ \\
\hline
\end{tabular}

terapii systemowej przerzutowych czerniaków. Chorzy na czerniaka z mutacją BRAF, u których stwierdzono bezobjawowe przerzuty do mózgu, mogą być w pierwszej kolejności poddani leczeniu inhibitorem BRAF.

Ponieważ inhibitory BRAF (+ inhibitory MEK) u chorych na zaawansowane czerniaki z mutacją BRAF powodują szybką odpowiedź i kontrolę nowotworu u większości chorych, przy ograniczonym czasie trwania odpowiedzi związanym z aktywacją mechanizmów oporności, leki te powinno się rozważać jako postępowanie z wyboru u chorych z objawami choroby i/lub dużą masą nowotworu. Szczególną korzyść z leczenia I linii odnoszą chorzy z wysoką aktywnością LDH. Nie ma ostatecznych danych dotyczących sekwencji stosowania immunoterapii i leczenia ukierunkowanego molekularnie u chorych na czerniaki z obecnością mutacji $B R A F$, choć aktywność inhibitorów BRAF jest zachowana również po immunoterapii, a immunoterapii (anty-PD-1)
- po leczeniu inhibitorami. W rzadkich przypadkach chorych na czerniaki z mutacją KIT obserwowano aktywność inhibitorów kinazy KIT [32].

\section{Obserwacja po leczeniu}

Częstotliwość i rodzaj badań oraz długość obserwacji należy uzależnić od indywidualnego ryzyka nawrotu choroby (co jest zależne od wyjściowego stopnia zaawansowania choroby), przy czym należy pamiętać o możliwości wystąpienia nawrotu po okresie ponad 10 lat od pierwotnego leczenia [33, 34] (tab. V). Ryzyko nawrotu jest największe w ciągu pierwszych 3 lat po leczeniu i dlatego rekomendowane schematy badań kontrolnych zalecają intensyfikację kontroli w tym okresie, głównie w celu wykrycia ewentualnego nawrotu lokoregionalnego, który wiąże się z możliwością wyleczenia metodami chirurgicznymi. Podstawą obserwacji po leczeniu jest ocena blizn po wy- 


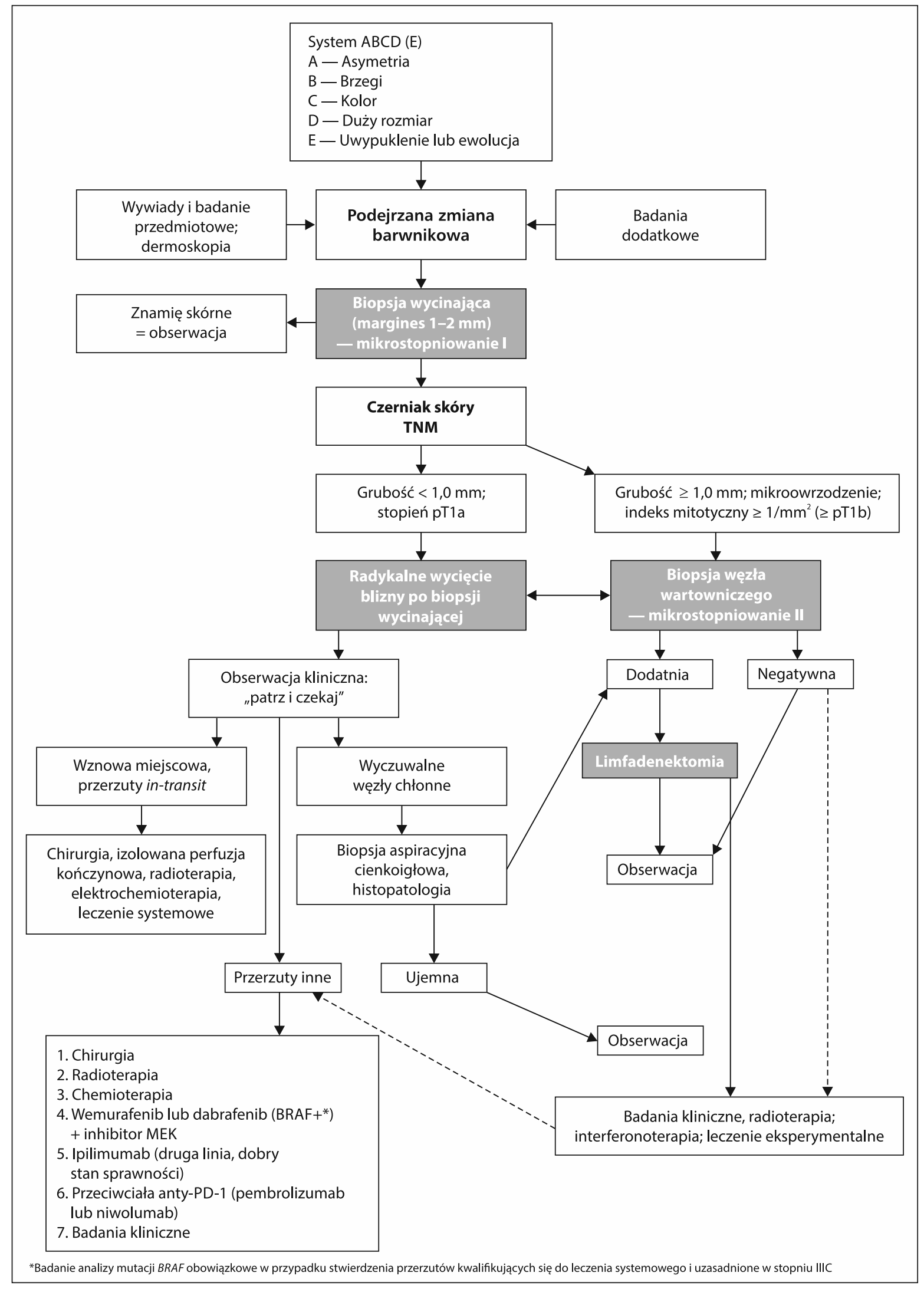

Rycina 2. Schemat postępowania diagnostyczno-terapeutycznego u chorych na czerniaki skóry 


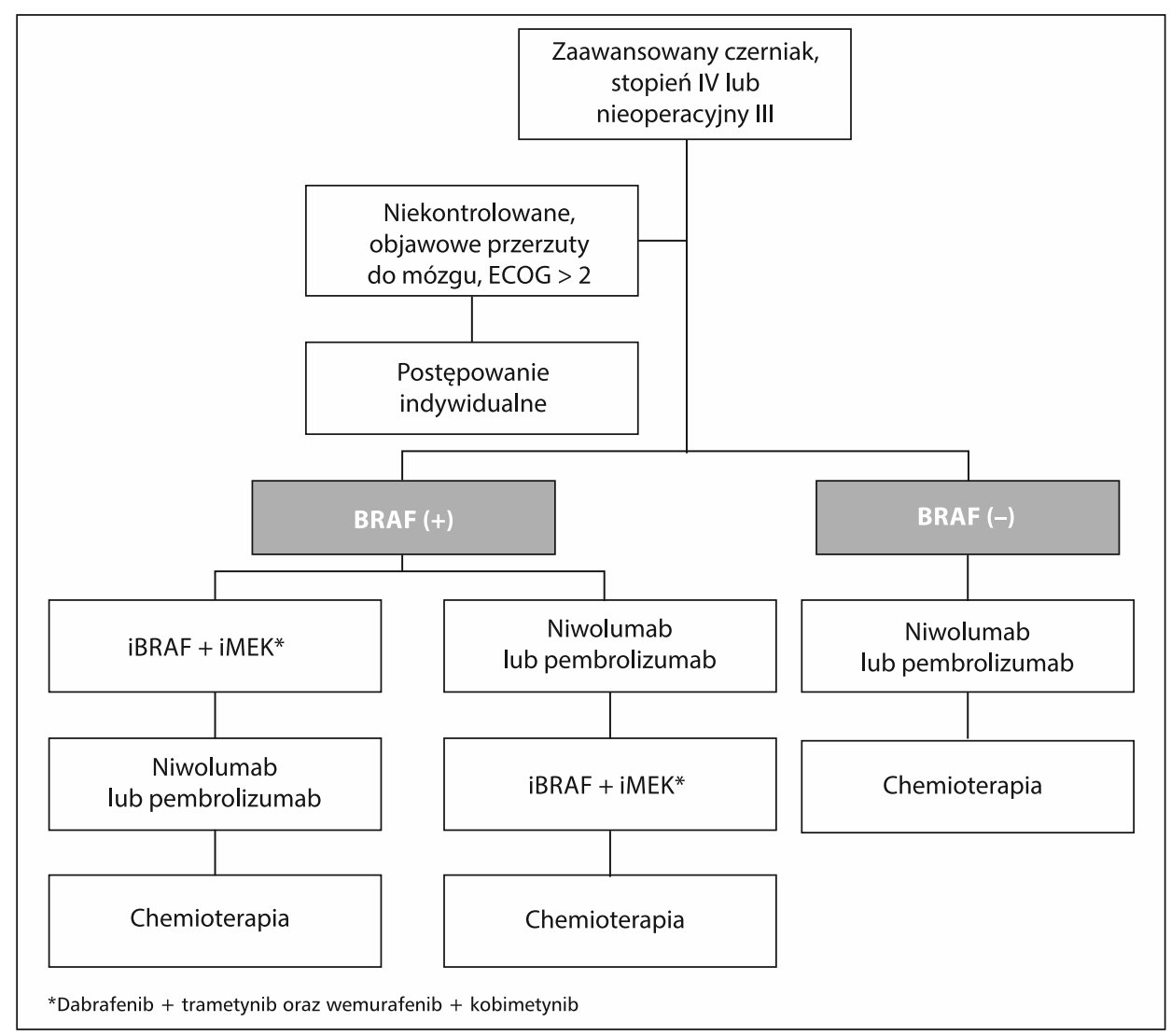

Rycina 3. Proponowany schemat leczenia systemowego u chorych na zaawansowane czerniaki w stopniu IV lub nieresekcyjnym III

cięciu ogniska pierwotnego i limfadenektomii. Szczególnej staranności wymaga ocena regionalnego spływu chłonnego (ewentualny rozsiew in-transit). Do oceny regionalnych węzłów chłonnych — oprócz palpacji — można stosować badanie USG. Ponieważ dużą część nawrotów lokoregionalnych może wykryć sam chory (nawet powyżej 60\%), należy uczulić pacjenta na przeprowadzanie samokontroli okolicy po wyciętym pierwotnym czerniaku oraz regionalnego spływu chłonnego. Istnieją przesłanki, że u chorych na czerniaki o mniejszym stopniu zaawansowania mniej intensywne schematy kontroli nie mają negatywnego wpływu na przeżycia.

Badania obrazowe nie są uzasadnione w obserwacji chorych w stopniach zaawansowania IA-IIA; można je rozważać przez pierwsze 2-3 lata (np. badanie TK) u bezobjawowych chorych w wyższych stopniach zaawansowania IIB-IIIC (biorąc pod uwagę pojawienie się w ostatnim czasie nowych skutecznych leków w terapii rozsianych czerniaków, gdyż wcześniejsze dane wykazywały minimalny zysk $\leq 2$ miesięcy w odniesieniu do spodziewanego wydłużenia przeżyć z powodu zastosowania intensywnych badań obrazowych). U chorych z klinicznymi objawami sugerującymi obecność przerzutów odległych (zaburzenia enzymów wątrobowych, bóle kości, objawy neurologiczne, kaszel i osłabienie) należy przeprowadzić bardziej specjalistyczne badania obrazowe, takie jak TK, MR, scyntygrafia.
Podczas badań kontrolnych obowiązuje badanie całej skóry chorego (w związku ze statystycznie większym prawdopodobieństwem rozwoju drugiego niezależnego ogniska czerniaka lub innego nowotworu skóry).

\section{Podsumowanie}

Biopsja wycinająca znamion atypowych i podejrzanych zmian barwnikowych, które mogą być wczesnymi czerniakami, ma podstawowe znaczenie dla postawienia rozpoznania i ustalenia najważniejszych czynników rokowniczych (mikrostopniowanie I). Istnieje powszechne przekonanie, że wcześniejsze rozpoznanie i usunięcie czerniaka nie tylko poprawia rokowanie, ale daje szanse wyleczenia u blisko $90 \%$ chorych. Zwykle zmiany barwnikowe o wymiarach do $2 \mathrm{~cm}$ w poprzecznej osi mogą być usunięte ambulatoryjnie w ramach wycięcia mieszczącego się w definicji biopsji wycinającej. Kolejne etapy postępowania obejmują kwalifikację chorych do radykalnego wycięcia blizny po biopsji wycinającej z właściwymi marginesami oraz wykonania biopsji węzła wartowniczego. W przypadku przerzutów do regionalnych węzłów chłonnych postępowaniem z wyboru jest wykonanie radykalnej limfadenektomii. Zaleca się włączanie chorych na czerniaki skóry o wysokim ryzyku nawrotu do prospektywnych badań klinicznych nad leczeniem uzupełniającym. Schemat postępowania diagnostyczno-terapeutycznego u chorych na czerniaki skóry przedstawiono na rycinach 2 i 3. 
Obecność przerzutów odległych nadal wiąże się ze złym rokowaniem. U chorych w stadium uogólnienia najbardziej właściwe jest stosowanie leczenia w ramach badań klinicznych. U chorych w stadium uogólnienia lub związanym z dużym ryzykiem nawrotu choroby (IIIC) zaleca się wykonanie badania stanu genu BRAF. Długoletnie przeżycia dotyczą głównie chorych poddanych resekcji pojedynczych ognisk przerzutowych. W systemowym leczeniu — przede wszystkim pierwszej linii — u chorych z obecnością mutacji BRAFV600 znajduje zastosowanie inhibitor BRAF (preferencyjnie w skojarzeniu z inhibitorem MEK) oraz — niezależnie od statusu mutacji BRAF — immunoterapia przeciwciałami anty-PD-1 (niwolumab lub pembrolizumab), ewentualnie ipilimumab (przeciwciało anty-CTLA4). Sekwencja leczenia (zwłaszcza w sytuacji obecności mutacji BRAF) nie jest obecnie określona. Zastosowanie leczenia skojarzonego inhibitorami BRAF i MEK jest związane z dużym odsetkiem odpowiedzi (około 70\%) i szybką poprawą objawów choroby, z kolei leczenie przeciwciałami anty-PD-1 przynosi mniejszy odsetek odpowiedzi, ale są one w większości długotrwałe.

\section{Konflikt interesów: nie zgłoszono}

\section{Prof. dr hab. med. Piotr Rutkowski}

Centrum Onkologii — Instytut im. Marii Skłodowskiej-Curie w Warszawie

Klinika Nowotworów Tkanek Miękkich, Kości i Czerniaków

ul. Roentgena 5, 02-781 Warszawa

e-mail:piotr.rutkowski@coi.pl

Otrzymano i przyjęto do druku: 25 października 2015 r.

\section{Piśmiennictwo}

1. RutkowskiP (red.). Złośliwe nowotwory skóry. Gdańsk:Via Medica, 2014.

2. Didkowska J, Wojciechowska U, Tarkowski Wi wsp. Warszawa: Nowotwory złośliwe w Polsce w 2012 roku, Centrum Onkologii — Instytut, 2014.

3. Rutkowski P, Wysocki P, Nowecki Z i wsp. Czerniaki skóry — zasady postępowania diagnostyczno-terapeutycznego w 2013 roku. Onkol Prak Klin 2012; 8: 219-233.

4. Dummer R, Hauschild A, Lindenblatt N i wsp. Cutaneous melanoma: ESMO Clinical Practice Guidelines for diagnosis, treatment and follow-up. Ann Oncol 2015; 26 (Suppl 5): v126-132.

5. NCCN Guidelines. Melanoma version 3.2015.

6. Balch CM, Gershenwald JE, Soong SJ i wsp. Final version of 2009 AJCC melanoma staging and classification. J Clin Oncol 2009; 27: 6199-6206.

7. Morton DL, Thompson JF, Cochran AJ i wsp. Final trial report of sentinel-node biopsy versus nodal observation in melanoma. N Engl J Med 2014; 370: 599-609.

8. Wong SL, Balch CM, Hurley $\mathrm{P}$ i wsp. Sentinel lymph node biopsy for melanoma: American Society of Clinical Oncology and Society of Surgical Oncology joint clinical practice guideline. J Clin Oncol 2012; 30: 2912-2918.

9. Nowecki Zl, Rutkowski P, Michej W. The survival benefit to patients with positive sentinel node melanoma after completion lymph node dissection may be limited to the subgroup with a primary lesion Breslow thickness greater than 1.0 and less than or equal to $4 \mathrm{~mm}$ (pT2-pT3). Ann Surg Oncol 2008; 15: 2223-2234.

10. van Akkooi AC, Nowecki Zl, Voit C i wsp. sentinel node tumor burden according to the Rotterdam criteria is the most important prognostic factor for survival in melanoma patients: a multicenter study in 388 patients with positive sentinel nodes. Ann Surg 2008; 248: 949-955.

11. Testori A, Rutkowski P, Marsden J i wsp. Surgery and radiotherapy in the treatment of cutaneous melanoma. Ann Oncol 2009; 20 Suppl 6: vi22-29.

12. Mali B, Jarm T, Snoj M i wsp. Antitumor effectiveness of electrochemotherapy: a systematic review and meta-analysis. Eur J Surg Oncol 2013; 39: 4-16.

13. Eggermont $\mathrm{AM}$, Gore M. Randomized adjuvant therapy trials in melanoma: surgical and systemic. Sem Oncol 2007; 34: 509-515.

14. SondakVK, Gonzalez RJ, Kudchadkar R. Adjuvant therapy for melanoma: a surgical perspective. Surg Oncol Clin N Am 2011; 20: 105-114.

15. Eggermont AM, Suciu S, Testori A i wsp. Ulceration and stage are predictive of interferon efficacy in melanoma: results of the phase III adjuvant trials EORTC 18952 and EORTC 18991. Eur J Cancer 2012; 48: 218-225.

16. Burmeister $\mathrm{BH}$, Henderson MA, Ainslie J i wsp. Adjuvant radiotherapy versus observation alone for patients at risk of lymph-node field relapse after therapeutic lymphadenectomy for melanoma: a randomised trial. Lancet Oncol 2012; 13: 589-597.

17. Ballo MT, Ang KK. Radiotherapy for cutaneous malignant melanoma: rationale and indications. Oncology 2004; 18: 99-107.

18. Hodi FS, O'Day SJ, McDermott DF i wsp. Improved survival with ipilimumab in patients with metastatic melanoma. NEJM 2010; 19; 363: 711-723.

19. Świtaj T, Wysocki P, Wojtukiewicz M i wsp. Ipilimumab - postęp $w$ terapii chorych na zaawansowanego czerniaka. Onkol Prakt Klin 2011; 7: 231-245.

20. Wolchok JD, Hoos A, O'Day S i wsp. Guidelines for the evaluation of immune therapy activity in solid tumors: immune-related response criteria. Clin Cancer Res 2009; 15: 7412-7420.

21. Robert C, Long GV, Brady B i wsp. Nivolumab in previously untreated melanoma without BRAF mutation. N Engl J Med 2015; 372: 320-330.

22. Weber JS, D'Angelo SP, Minor D i wsp. Nivolumab versus chemotherapy in patients with advanced melanoma who progressed after anti-CTLA-4 treatment (CheckMate 037): a randomised, controlled, open-label, phase 3 trial. Lancet Oncol 2015; 16: 375-384.

23. Robert C, Schachter J, Long GV i wsp. Pembrolizumab versus I pilimumab in Advanced Melanoma. N Engl J Med 2015; 372: 2521-2532.

24. Larkin J, Chiarion-Sileni V, Gonzalez R i wsp. Combined Nivolumab and Ipilimumab or Monotherapy in Untreated Melanoma. N Engl J Med 2015; 373: 23-34.

25. Chapman PB, Hauschild A, Robert $C$ i wsp. Improved survival with vemurafenib in melanoma with BRAF V600E mutation. $N$ Engl J Med 2011; 364: 2507-2516.

26. Hauschild A, Grob JJ, Demidov LV i wsp. Dabrafenib in BRAF-mutated metastatic melanoma: a multicentre, open-label, phase 3 randomised controlled trial. Lancet 2012; 380: 358-365.

27. Flaherty KT, Robert C, Hersey P i wsp. Improved survival with MEK inhibition in BRAF-mutated melanoma. NEng/JMed 2012; 367: 107-114.

28. Ascierto PA, Berking C, Agarwala SS i wsp. Efficacy and safety of oral MEK162 in patients with locally advanced and unresectable or metastatic cutaneous melanoma harboring BRAFV600 or NRAS mutations. J Clin Oncol 2012; 30 (Suppl); Abstr 8511.

29. Robert C, Karaszewska B, Schachter J i wsp. Improved overall survival in melanoma with combined dabrafenib and trametinib. NEngl J Med 2015; 372: 30-39.

30. Long GV, Stroyakovskiy D, Gogas H i wsp. Dabrafenib and trametinib versus dabrafenib and placebo for Val600 BRAF-mutant melanoma: a multicentre, double-blind, phase 3 randomised controlled trial. Lancet 2015; 386: 444-451.

31. Larkin J, Ascierto PA, Dréno B i wsp. Combined vemurafenib and cobimetinib in BRAF-mutated melanoma. N Engl J Med 2014; 371: 1867-1876.

32. Guo J, Si L, Kong Y i wsp. Phase II, open-label, single-arm trial of imatinib mesylate in patients with metastatic melanoma harboring c-Kit mutation or amplification. J Clin Oncol 2011; 29: 2904-2909.

33. Jassem J, Duchnowska R, Kawecki A i wsp. Badania kontrolne po leczeniu w najczęstszych nowotworach litych u dorosłych. Nowotwory J Oncol 2014; 64: 5: 415-435.

34. Rutkowski P, Ługowska I. Follow-up in melanoma patients. Memo 2014; 7: 83-86. 